\title{
Medication management during electroconvulsant therapy
}

\author{
This article was published in the following Dove Press journal: \\ Neuropsychiatric Disease and Treatment \\ 19 April 2016 \\ Number of times this article has been viewed
}

\section{Monica Zolezzi \\ Clinical Pharmacy and Practice, College of Pharmacy, Qatar University, Doha, Qatar}

\begin{abstract}
Electroconvulsive therapy (ECT) has demonstrated to be highly effective and safe, even life saving for many psychiatric disorders such as major depression, bipolar disorder and schizophrenia. Most patients who require ECT are also on concurrent pharmacotherapy. As such, the objective of this article is to provide a review of the most recent literature focusing on the medications used during an ECT procedure and on the effects of concurrent psychiatric and non-psychiatric medications on the effectiveness and safety of ECT. The review also attempts to summarize the recommendations derived from existing documents to guide pharmacotherapy decisions for patients undergoing ECT. For this purpose, using electronic databases, an extensive search of the current literature was made using ECT and medications or drug classes as keywords.
\end{abstract}

Keywords: ECT, medications, drug interactions

\section{Introduction}

Several evidence-based documents on the use of electroconvulsive therapy (ECT) indicate that it is a safe and effective treatment for a variety of psychiatric disorders. ${ }^{1-3}$ Although major depression refractory to antidepressant medications is the primary indication for ECT, there is also significant evidence to support its use in other psychiatric disorders such as catatonia, psychotic depression, mania, bipolar disorder and schizophrenia. ${ }^{1-3}$

The goal of ECT is to produce a controlled and monitored seizure lasting from 30 to 90 seconds in duration to be considered therapeutic. ${ }^{1,4-6}$ Although the exact mechanism of ECT is unknown, the induced seizure affects nearly every neurotransmitter system, including $\beta$-adrenergic, serotonin, muscarinic, cholinergic, and dopaminergic systems. ${ }^{6,7}$ Brain-derived neurotrophic factor may also play a role in the efficacy of ECT. ${ }^{8}$ There are no absolute contraindications to ECT; nevertheless, ECT can induce side effects and may be physically risky for certain individuals. As such, all patients must be assessed prior to ECT for the presence of conditions such as cardiovascular disease, space-occupying intracranial lesion with the evidence of elevated intracranial pressure, recent cerebral hemorrhage or stroke, bleeding or otherwise unstable vascular aneurysm, and severe pulmonary disease, as all of these can be associated with increased risk of complications from the general anesthesia and induction of seizure activity. ${ }^{1}$ ECT is considered safe with a mortality of $\sim 1 / 10,000$ patients or 1/80,000 treatments. ${ }^{6}$ Most patients report some adverse cognitive effects during and after a course of ECT, such as postictal confusion state (the result of both anesthesia and the seizure), anterograde amnesia (decreased ability to retain newly acquired
Correspondence: Monica Zolezzi Clinical Pharmacy and Practice, College of Pharmacy, Qatar University, PO Box 2713, Doha, Qatar

Tel +97444035 623

Fax+9744403555

Email mzolezzi@qu.edu.qa 
information), and retrograde amnesia (forgetting recent memories). ${ }^{9}$ However, objective tests indicate that cognitive abnormalities caused by ECT are generally short lived. Acute confusional states typically resolve 10 to 30 minutes after the procedure, whereas anterograde amnesia resolves within 2 weeks after completing the course. Retrograde amnesia recovers more slowly than anterograde amnesia. ${ }^{10}$ Permanent memory loss is rare but can occur. ${ }^{9,11}$ Other adverse effects include myalgias, headache, nausea, drowsiness, and musculoskeletal weakness. ${ }^{1,4-7}$

Several parameters have the potential to influence the induction of a well-organized seizure, which is critical for ECT efficacy, such as electric stimuli, seizure threshold, and medications, including those used during the ECT procedure itself, as well as those regularly used to treat the individual's concomitant psychiatric or medical conditions. ${ }^{12}$ As such, assessing all concurrent medications and monitoring for the potential effects of these medications before, during, and after the ECT procedure are recommended. ${ }^{1-3,6,7}$ This article aims to review all the different classes of medications that may be used in patients undergoing ECT and their influence on ECT outcomes. Most of the available guidelines describing medications used in ECT are a decade old, and thus, an update on this topic is warranted.

A review of the literature was undertaken using Medline (OvidSP), PubMed Central, and Google Scholar using the keywords "electroconvulsive therapy", "drug(s)", "medication(s)", and "drug/medication interactions". Only studies with human subjects, reports written in the English language and published after January 1, 2000, were included. Additional references were identified from the bibliographies of published review articles regardless of the date of publication and from ECT guidelines. ${ }^{1-3}$ In addition, using the same electronic databases, separate searches were undertaken using ECT and various drugs or drug classes as keywords.

The findings have been summarized as 1) medications that are used during the ECT procedure and 2) interactions between regularly prescribed medications and medications used during the ECT procedure itself. Management strategies for these medication interactions have also been extracted from the retrieved articles whenever available to help clinicians in making decisions about which medications to taper or stop before the procedure, which medications can safely be given just before the procedure, and which can be continued during the course of ECT (or held until after each treatment).

\section{Medications during the ECT procedure}

Table 1 lists common medications that patients may receive during an ECT procedure. These include anesthetic induction agents, anticholinergic agents, muscle relaxants, antihypertensives, and narcotics.

Anesthetic agents and muscle relaxants are used to induce a state of insensibility and to decrease the likelihood of bone and soft tissue injury. ${ }^{1}$ Due to the brief nature of ECT, an ideal anesthetic agent should rapidly induce hypnosis and allow for rapid emergence from anesthesia without significantly shortening seizure activity or causing hemodynamic instability. ${ }^{13,14}$ Among the barbiturates, methohexital and thiopental, which have minimal anticonvulsant properties compared with other barbiturates, were considered as gold standard as ECT anesthetic induction agents, but due to recent worldwide shortages of these agents, other drugs such as propofol, etomidate and ketamine have become more widely used. ${ }^{15-21}$

The advantages of propofol over methohexital include a quicker and smoother emergence from anesthesia and a somewhat more favorable hemodynamic profile. ${ }^{14-17}$ Disadvantages are its much greater anticonvulsant effect and higher cost. Etomidate is an alternative particularly in patients who have seizures of short duration or hard to elicit. ${ }^{14,17,20}$ Ketamine has shown to be slightly proconvulsant and has intrinsic antidepressant properties. Disadvantages include hypertension and occasional transient dissociative symptoms on wake up. ${ }^{17,19,21}$ A recent systematic review concluded that robust evidence to recommend a particular induction agent for ECT is lacking and indicated that anesthetic agents should

Table I Medications during the ECT procedure

\begin{tabular}{ll}
\hline Anesthetic induction & Methohexital \\
agents & Thiopental \\
& Propofol \\
& Etomidate \\
& Ketamine \\
& Succinylcholine (suxamethonium) \\
Neuromuscular & Rocuronium \\
blocking agents & Atracurium \\
& Mivacurium \\
Antihypertensives & $\beta$-blockers (atenolol, esmolol, and labetalol) \\
& Calcium channel blockers (nifedipine and \\
Anticholinergic & nicardipine) \\
agents & Glycopyrrolate \\
Narcotics & Atropine \\
& Fentanyl \\
& Remifentanyl \\
& Alfentanyl
\end{tabular}

Abbreviation: ECT, electroconvulsive therapy. 
be chosen on the basis of adverse effect profile, emergence, and how these medications affect seizure duration..$^{18}$ Opioids, such as remifentanil and alfentanil, combined with anesthetic agents have been used to increase the seizure duration by an induction agent dose-sparing effect. ${ }^{17,22-24}$ Caffeine, in the form of caffeine sodium benzoate intravenous injection 250-1,000 $\mathrm{mg}$, and other methylxanthines have also been administered prior to ECT to increase the seizure duration but do not appear to reduce seizure threshold. ${ }^{24}$ However, because the potential cardiac and other complications of caffeine use are known, this augmenting strategy is not generally recommended, especially in the elderly. ${ }^{24,25}$ Muscle relaxation during the application of the stimulus, as well as for the duration of the motor portion of the seizure, prevents musculoskeletal injury; this is especially important if the patient has osteoporosis or a history of spinal injury. ${ }^{1,6,7}$ Because of the short duration of ECT, succinylcholine (also known as suxamethonium) is the drug of choice for neuromuscular blockade. ${ }^{1,17,26}$ Succinylcholine is a depolarizing neuromuscular blocker with an ultrashort duration of action, slightly less than that of the anesthetic agent. The duration of muscle paralysis is, thus, very brief, and spontaneous respirations return shortly after the seizure ends. In patients in whom its use is contraindicated, rocuronium or other nondepolarizing agents are alternatives. ${ }^{1,26}$

During ECT, significant changes in autonomic function can occur. Initially a parasympathetic surge can result in significant bradycardia, hypotension, and, in some cases, brief asystole. ${ }^{1,6}$ Patients already on $\beta$-blockers may be at risk of bradycardia if stimulation is given but a seizure is not induced. ${ }^{4,7}$ To counteract the parasympathetic effect, anticholinergic medications (eg, glycopyrrolate and atropine) may be given, although this is not routinely required. Glycopyrrolate is preferred over atropine since it does not cross the blood-brain barrier, which reduces unwanted cognitive effects after ECT. ${ }^{6}$

Following stimulus termination, the resulting seizure is accompanied by a profound sympathetic surge, typically associated with tachycardia and hypertension. ${ }^{1,27}$ Deleterious sympathetic effects may be controlled with $\beta$-blockers either pre- (atenolol) or intraprocedurally (labetalol and esmolol). ${ }^{13,17}$ There is controversy, however, regarding whether labetalol and esmolol reduce seizure duration. ${ }^{28}$ Sublingual nifedipine and intravenous nicardipine have been used (although tachycardia can occur), as has diltiazem, although it also may reduce seizure duration. ${ }^{27}$ Preoperative $\alpha-2$ agonists, such as dexmedetomidine, also blunt the hyperdynamic response as does glyceryl trinitrate, which should be considered in patients at high risk of myocardial ischemia. ${ }^{17,27,28}$

\section{Interactions between regularly prescribed medications and ECT}

The majority of patients requiring ECT are likely to be receiving concurrent regularly prescribed medications for treating psychiatric, medical, and comorbid conditions. Therefore, not surprisingly, drug interactions can occur between psychotropic agents, drugs prescribed for chronic medical conditions, anesthesia-inducing agents, and other medications used for the ECT procedure itself. These drug interactions can be classified into the following categories: 1) interactions with medications used during the ECT procedure, 2) interactions that affect the efficacy of ECT (ie, suppressing seizure activity), and 3) interactions that can increase the risks associated with ECT (eg, increase risk of complications, such as prolonged seizures and cardiotoxicity).

In general, medications that raise seizure threshold or impede seizure propagation (interfere with induction or spread of a robust seizure) should be avoided if possible, or the dose decreased (eg, anticonvulsants and benzodiazepines). Cardiac medications, antihypertensives, and antigastric medications can typically be continued. Table 2 provides a summary of the most often reported drug interactions based on the major classes of commonly used medications by patients undergoing ECT. For each specific drug interaction, the possible undesired effect and how it can be managed are also included for easy reference. There are no studies exploring the effects of herbal medicines on ECT; however, several direct and indirect mechanisms whereby such use may impact the ECT procedure are also summarized in Table 2.

\section{Conclusion}

Despite the vast potential for drug interactions in patients receiving ECT, available evidence on those interactions that are clinically significant is scarce, and it is almost exclusively retrospective in nature, or derived from case reports or case series. A summary of the existing evidence as presented in this article can inform clinicians on the potential and documented consequences of these interactions, and assist them weighing the risks and benefits before making decisions on the concurrent use of medications in patients receiving ECT. 
Table 2 Drug interactions reported in patients undergoing ECT

\begin{tabular}{|c|c|c|c|}
\hline Class & Evidence & Possible undesired effect & Management strategies \\
\hline \multicolumn{4}{|c|}{ Anticonvulsants/mood stabilizers } \\
\hline Lithium $6,29-31$ & $\begin{array}{l}\text { - Combination has a significant risk } \\
\text { of delirium, prolonged seizures, } \\
\text { toxic lithium levels, and prolonged } \\
\text { neuromuscular blockade } \\
\text { - Combination not an absolute } \\
\text { contraindication. In certain } \\
\text { emergencies where the benefits } \\
\text { clearly outweigh the risks, } \\
\text { combined therapy could be } \\
\text { considered } \\
\text { - Case reports in elderly patients } \\
\text { indicate that only } 24 \text { hours of } \\
\text { holding lithium therapy might } \\
\text { result in a lithium level sufficient } \\
\text { to contribute to delirium } \\
\text { after ECT }\end{array}$ & $\begin{array}{l}\text { - Delirium, postictal confusion (the } \\
\text { elderly may be at increased risk) } \\
\text { - Prolonged seizure duration } \\
\text { - Increased lithium levels } \\
\text { - Prolonged action of neuromuscular } \\
\text { blocking agents (eg, succinylcholine) } \\
\text { - Potential serotonin syndrome }\end{array}$ & $\begin{array}{l}\text { - Avoid combination if possible } \\
\text { - lithium cannot be discontinued, } \\
\text { level in the lowest therapeutic } \\
\text { range and/or hold day before ECT } \\
\text { - If patient is already taking lithium } \\
\text { without clear benefit, stop lithium } \\
\text { before ECT. A washout period } \\
\text { is unnecessary unless high blood } \\
\text { level is present } \\
\text { - If lithium has provided clear } \\
\text { benefit, lithium can be continued } \\
\text { during index ECT, with close } \\
\text { monitoring for unwanted adverse } \\
\text { effects at the lowest possible } \\
\text { therapeutic level } \\
\text { - Alternatively, substitute lithium } \\
\text { for another mood stabilizer (eg, } \\
\text { atypical antipsychotic) to provide } \\
\text { protection against mania while } \\
\text { ECT is being given for depression } \\
\text { - Nondepolarizing neuromuscular } \\
\text { blockers should be administered } \\
\text { in incremental and reduced doses } \\
\text { and titrated to the degree of block } \\
\text { required }\end{array}$ \\
\hline VPA $^{14,32-34}$ & $\begin{array}{l}\text { - Case reports of difficulty in } \\
\text { eliciting seizures with patients } \\
\text { on VPA } \\
\text { - Possible drug-drug interaction } \\
\text { competing for protein binding, } \\
\text { which can elevate VPA levels } \\
\text { - Decrease in the propofol dose } \\
\text { required to induce anesthesia } \\
\text { during ECT in the presence } \\
\text { of VPA }\end{array}$ & $\begin{array}{l}\text { - Seizure inhibition or difficulty in } \\
\text { eliciting adequate seizures during ECT } \\
\text { - Theoretically, the anticonvulsant } \\
\text { activity of VPA may interact with the } \\
\text { efficacy of ECT }\end{array}$ & $\begin{array}{l}\text { Dose reduction or withholding } \\
\text { doses (eg, the morning of, or the } \\
\text { evening or morning prior to the } \\
\text { ECT procedure) } \\
\text { - Changing the anesthetic regimen } \\
\text { (addition of remifentanyl to a } \\
\text { lower dose of methohexital, } \\
\text { or etomidate instead of } \\
\text { methohexital), to produce } \\
\text { adequate seizures }\end{array}$ \\
\hline $\mathrm{CBZ}^{14,32,33}$ & $\begin{array}{l}\text { - Case reports show mixed results. } \\
\text { Some indicate no negative effect } \\
\text { of CBZ on ECT, and others } \\
\text { report difficulty in eliciting } \\
\text { seizures } \\
\text { - CBZ-ECT group compared to } \\
\text { control group had a shorter } \\
\text { duration of seizures and a higher } \\
\text { stimulus dose when unilateral } \\
\text { treatments were used } \\
\text { - Development of moderately } \\
\text { severe postictal confusion has also } \\
\text { been reported } \\
\text { - CBZ may prolong the action } \\
\text { of succinylcholine (few clinical } \\
\text { implications) } \\
\text { - Long-term CBZ demonstrated } \\
\text { resistance to nondepolarizing } \\
\text { neuromuscular blockers (except } \\
\text { mivacurium) }\end{array}$ & $\begin{array}{l}\text { - Seizure inhibition } \\
\text { - Accelerated recovery and need for } \\
\text { increased doses to achieve complete } \\
\text { neuromuscular block (induce a } \\
\text { mild upregulation of neuromuscular } \\
\text { acetylcholine) }\end{array}$ & $\begin{array}{l}\text { Dose reduction or withholding } \\
\text { doses (eg, the morning of, or the } \\
\text { evening or morning prior to the } \\
\text { ECT procedure) } \\
\text { - Neuromuscular blockade: if } \\
\text { suxamethonium is contraindicated, } \\
\text { mivacurium seems to be the } \\
\text { preferred neuromuscular blocker } \\
\text { in patients receiving CBZ therapy }\end{array}$ \\
\hline
\end{tabular}


Table 2 (Continued)

\begin{tabular}{|c|c|c|c|}
\hline Class & Evidence & Possible undesired effect & Management strategies \\
\hline $\operatorname{LTG}^{14,32,34,35}$ & $\begin{array}{l}\text { - Case reports/series show minimal } \\
\text { or no influence on seizures and/or } \\
\text { seizure duration } \\
\text { - Interaction with halothane; } \\
\text { reducing effect of LTG on } \\
\text { glutamate release, either at the } \\
\text { receptor or via effects at the } \\
\text { inactivated sodium channel } \\
\text { - ECT attenuates the inhibitory } \\
\text { dose-dependent effects of LTG } \\
\text { on synaptic transmission at a low } \\
\text { frequency. Clinical significance } \\
\text { remains unknown }\end{array}$ & - Theoretically, seizure inhibition & - None have been recommended \\
\hline $\begin{array}{l}\text { Others: } \\
\text { gabapentin }{ }^{14,32,34} \\
\text { and topiramate }\end{array}$ & $\begin{array}{l}\text { - No complications were found in } \\
\text { two case reports using gabapentin } \\
\text { - No interactions have as yet been } \\
\text { reported between gabapentin or } \\
\text { topiramate and the anesthetics } \\
\text { used for ECT } \\
\text { - The use of topiramate for post- } \\
\text { ECT headaches did not result in } \\
\text { adverse ECT outcomes }\end{array}$ & - Theoretically, seizure inhibition & - None have been recommended \\
\hline \multicolumn{4}{|l|}{ Antidepressants } \\
\hline MAOI $4,14,37-39$ & $\begin{array}{l}\text { - No evidence of an interaction } \\
\text { between ECT and MAOI use } \\
\text { - A prospective study looked at } \\
\text { the risks associated with the } \\
\text { combination of MAOls and ECT, } \\
\text { no differences between the study } \\
\text { and control groups were reported } \\
\text { - Ketamine should be avoided as it } \\
\text { causes sympathetic stimulation. } \\
\text { Propofol and etomidate can be } \\
\text { used safely with MAOls }\end{array}$ & $\begin{array}{l}\text { - Theoretically, risk of hypertensive } \\
\text { crisis if combined with indirect acting } \\
\text { sympathomimetics }\end{array}$ & $\begin{array}{l}\text { - Usual recommendation for the } \\
\text { combination of MAOI with other } \\
\text { medications should be provided to } \\
\text { avoid hypertensive crises } \\
\text { - If the MAOI has not been } \\
\text { effective, a cautious approach } \\
\text { when discontinuing the MAOI } \\
\text { before ECT is recommended. } \\
\text { There is no need for a washout } \\
\text { period before starting ECT } \\
\text { - If the medication has been helpful, } \\
\text { the MAOI can be continued. } \\
\text { Alternatively, patients could be } \\
\text { switched to a reversible MAOI } \\
\text { (eg, moclobemide) as it carries a } \\
\text { decreased risk }\end{array}$ \\
\hline $\mathrm{TCA}^{4,6,14,39,40}$ & $\begin{array}{l}\text { Retrospective review of the } \\
\text { literature found that the use } \\
\text { of TCAs in combination with } \\
\text { ECT was associated with better } \\
\text { outcomes and shorter total } \\
\text { seizure time than with ECT alone } \\
\text { - No differences were found in } \\
\text { the measures of confusion and } \\
\text { cardiac adverse effects, and there } \\
\text { was even a trend toward fewer } \\
\text { adverse effects in the groups } \\
\text { receiving the ECT and TCA } \\
\text { combination }\end{array}$ & $\begin{array}{l}\text { Theoretically, reduced seizure } \\
\text { threshold and an increased risk of } \\
\text { cardiotoxicity } \\
\text { - Chronic therapy with TCAs depletes } \\
\text { cardiac catecholamines, potentiating } \\
\text { the cardiac depressant effects of } \\
\text { anesthetic agents }\end{array}$ & $\begin{array}{l}\text { - The TCA dose should be } \\
\text { decreased if possible to minimize } \\
\text { the likelihood of an exaggerated } \\
\text { hypertensive response during ECT } \\
\text { - Abrupt withdrawal of TCAs } \\
\text { should be avoided because of } \\
\text { the risk of mainly cholinergic } \\
\text { symptoms } \\
\text { - Best avoid TCA use in the } \\
\text { elderly and in those with cardiac } \\
\text { conditions }\end{array}$ \\
\hline Others $^{1,4,14,39-45}$ & $\begin{array}{l}\text { Minimal effect on ECT-related } \\
\text { seizure duration has been } \\
\text { reported with SSRIs, SNRIs, or } \\
\text { trazodone }\end{array}$ & $\begin{array}{l}\text { - Theoretically, reduced seizure } \\
\text { threshold with SSRIs and SNRIs } \\
\text { - Seizure length may increase when } \\
\text { ECT is administered during bupropion } \\
\text { treatment }\end{array}$ & $\begin{array}{l}\text { - Some clinicians recommend } \\
\text { bupropion discontinuation or dose } \\
\text { reduction prior to ECT }\end{array}$ \\
\hline
\end{tabular}


Table 2 (Continued)

\begin{tabular}{|c|c|c|c|}
\hline Class & Evidence & Possible undesired effect & Management strategies \\
\hline & $\begin{array}{l}\text { - Possibility of increased risk of } \\
\text { asystole with venlafaxine (SNRI) } \\
\text { at doses }>300 \mathrm{mg} / \mathrm{d} \\
\text { - Status epilepticus has been } \\
\text { reported with concomitant use of } \\
\text { bupropion during ECT } \\
\text { - Serotonin syndrome has been } \\
\text { reported with paroxetine and } \\
\text { fluoxetine }\end{array}$ & $\begin{array}{l}\text { - Pharmacokinetic interactions with } \\
\text { some SSRIs and anesthetic agents }\end{array}$ & $\begin{array}{l}\text { - If SSRIs are discontinued, clinicians } \\
\text { should be aware that withdrawal } \\
\text { may cause symptoms similar } \\
\text { to the side effects of ECT (eg, } \\
\text { headache, myalgia, nausea, and } \\
\text { fatigue) } \\
\text { - It is necessary to pay attention to } \\
\text { the rare side effect of serotonin } \\
\text { syndrome by ECT in combination } \\
\text { with SSRIs }\end{array}$ \\
\hline \multicolumn{4}{|c|}{ Anxiolytics } \\
\hline $\mathrm{BZD}^{6,14,39}$ & $\begin{array}{l}\text { The impact of BZDs on seizure } \\
\text { adequacy may be low if the BZD } \\
\text { has been routinely used } \\
\text { - Can produce additive sedative } \\
\text { effects during the anesthetic } \\
\text { induction phase }\end{array}$ & $\begin{array}{l}\text { - Increased seizure threshold, } \\
\text { decreased seizure duration, and } \\
\text { decreased potential efficacy of ECT } \\
\text { - Possibly increased cognitive side } \\
\text { effects when given with ECT }\end{array}$ & $\begin{array}{l}\text { - If possible, stop BZD before ECT. } \\
\text { Many BZDs are long acting and } \\
\text { may need to be discontinued } \\
\text { some days before ECT } \\
\text { - If the BZD cannot be } \\
\text { discontinued, the use of higher } \\
\text { stimulus or using flumazenil } \\
\text { just before ECT to temporarily } \\
\text { reverse effects of the BZD has } \\
\text { been suggested } \\
\text { - The dose of thiopental or } \\
\text { propofol used for induction of } \\
\text { anesthesia should be titrated to } \\
\text { the desired effect }\end{array}$ \\
\hline \multicolumn{4}{|c|}{ Antipsychotics } \\
\hline $\mathrm{FGA}^{1,14,39,46}$ & $\begin{array}{l}\text { The combination of FGAs, } \\
\text { particularly phenothiazines (eg, } \\
\text { chlorpromazine) and ECT has } \\
\text { been reported to cause prolonged } \\
\text { seizures }\end{array}$ & $\begin{array}{l}\text { - Theoretically, FGAs reduce seizure } \\
\text { threshold }\end{array}$ & $\begin{array}{l}\text { - None have been recommended } \\
\text { - Their antiadrenergic and } \\
\text { anticholinergic effects are } \\
\text { unpredictable, and caution in the } \\
\text { use of drugs with similar effects } \\
\text { during anesthesia should be } \\
\text { exercised }\end{array}$ \\
\hline $\mathrm{SGA}^{14,39,46}$ & $\begin{array}{l}\text { Some data suggest beneficial } \\
\text { and additive efficacy when in } \\
\text { combination, particularly with } \\
\text { clozapine }\end{array}$ & $\begin{array}{l}\text { Clozapine is known to decrease } \\
\text { the seizure threshold in a dose- } \\
\text { dependent manner (usually at doses } \\
>600 \mathrm{mg} / \mathrm{d} \text { ) }\end{array}$ & $\begin{array}{l}\text { - None have been recommended } \\
\text { - For patients on clozapine, a dose } \\
\text { reduction prior to ECT may be } \\
\text { considered }\end{array}$ \\
\hline
\end{tabular}

Methylphenidate ${ }^{14}$

\section{Miscellaneous}

Cholinesterase inhibitors ${ }^{4,47,48}$

Lidocaine $\mathrm{l}^{1,7,17,49,50}$
- Methylphenidate was shown to reduce sedation and improve respiratory function in patients recovering from halothane anesthesia

- No evidence of adverse incidents involving concurrent use with ECT

- Successful use of donepezil in treating cognitive deficits associated with maintenance ECT has been reported

- Ineffective in ameliorating the robust sympathetic response associated with ECT
- Theoretically, there is an increased risk for potentiating seizure activity, thereby leading to prolonged seizures or a risk for status epilepticus

- Methylphenidate can also produce dysrhythmias and elevate blood pressure during anesthesia

- Theoretically, synergistic effects with neuromuscular blocking agents. This combination also has the potential to induce significant bradycardia, cardiac arrhythmias, and asystole

- Seizure inhibition

- Potentially useful for reducing tachycardia in high-risk patients and reducing the severity of propofol injection pain
- None have been recommended

- Caution has been recommended particularly with neuromuscular blocking agents

- Recommended to be used only in life threatening situations to control heart rate, when $\beta$-blockers are not available or are contraindicated 
Table 2 (Continued)

\begin{tabular}{|c|c|c|c|}
\hline Class & Evidence & Possible undesired effect & Management strategies \\
\hline Theophylline ${ }^{4,6,14}$ & $\begin{array}{l}\text { - Pretreatment with lidocaine is } \\
\text { associated with decreased seizure } \\
\text { duration and a higher likelihood } \\
\text { of patients requiring multiple } \\
\text { applications of electric current } \\
\text { during a single ECT session to } \\
\text { achieve a therapeutic seizure } \\
\text { - Reports of status epilepticus after } \\
\text { ECT } \\
\text { - High levels of theophylline during } \\
\text { ECT associated with status } \\
\text { epilepticus }\end{array}$ & $\begin{array}{l}\text { - Can increase seizure duration and } \\
\text { increase risk of status epilepticus }\end{array}$ & $\begin{array}{l}\text { - If possible, discontinue } \\
\text { theophylline by tapering the } \\
\text { dose. Continue with a regimen } \\
\text { of bronchodilators and inhaled } \\
\text { glucocorticoids } \\
\text { - Alternatively, decrease dose to } \\
\text { the lowest therapeutic drug level } \\
\text { and monitor levels closely } \\
\text { - Provide standard treatment during } \\
\text { an asthma exacerbation (inhaled } \\
\beta \text {-agonists and, if necessary, } \\
\text { glucocorticoids, before proceeding } \\
\text { with ECT) }\end{array}$ \\
\hline $\begin{array}{l}\text { Antigastric agents } \\
\text { (eg, antacids and } \\
\text { proton pump } \\
\text { inhibitors) })^{6,51}\end{array}$ & $\begin{array}{l}\text { - No evidence of adverse incidents } \\
\text { involving concurrent use with } \\
\text { ECT }\end{array}$ & & $\begin{array}{l}\text { - Continue as patients with GERD } \\
\text { may have worsened symptoms } \\
\text { undergoing ECT due to vagal } \\
\text { stimulation }\end{array}$ \\
\hline $\begin{array}{l}\text { Diabetic } \\
\text { agents (eg, oral } \\
\text { hypoglycemics } \\
\text { and insulin) }\end{array}$ & $\begin{array}{l}\text { Individual ECT treatments raise } \\
\text { blood glucose levels in patients } \\
\text { with diabetes to the same degree } \\
\text { as in patients without diabetes }\end{array}$ & - Can cause hypoglycemia & $\begin{array}{l}\text { - Measure blood glucose levels } \\
\text { before and after ECT treatment. } \\
\text { Give half the usual amount of } \\
\text { long-acting insulin in the morning } \\
\text { of the procedure } \\
\text { - Withhold oral agents until patient } \\
\text { can eat. Provide short-acting } \\
\text { insulin to treat elevations in blood } \\
\text { glucose level }\end{array}$ \\
\hline Warfarin ${ }^{51-53}$ & $\begin{array}{l}\text { - A retrospective case review } \\
\text { found that over one-third of the } \\
\text { patients INRs during ECT were } \\
\text { subtherapeutic } \\
\text { - However, ECT appears to be safe } \\
\text { in patients who require long-term } \\
\text { anticoagulation }\end{array}$ & $\begin{array}{l}\text { The potential for methohexital to } \\
\text { increase the metabolism of warfarin, } \\
\text { decrease the INR, and possibly affect } \\
\text { warfarin's efficacy exists }\end{array}$ & $\begin{array}{l}\text { Continue anticoagulation to } \\
\text { maintain an INR of up to } 3.5 \text {, } \\
\text { unless there is an increased risk } \\
\text { of intracranial hemorrhage (eg, } \\
\text { intracranial mass or aneurysm) }\end{array}$ \\
\hline Herbals $^{54}$ & \multicolumn{2}{|c|}{ Mechanism of action and potential effect on ECT } & Management strategies \\
\hline Gingko biloba & \multirow{2}{*}{\multicolumn{2}{|c|}{$\begin{array}{l}\text { - GABA agonist: potentiates CNS depressant effects of barbiturates and BZDs } \\
\text { and may increase ECT seizure threshold } \\
\text { - Inhibit platelet activating factor: increase risk of cerebral hemorrhage } \\
\text { - May contain convulsive agent: lower ECT seizure threshold } \\
\text { - Cerebral arterial vasodilation: increased intracranial pressure } \\
\text { - Induce CYP3A4: increase metabolism of barbiturates and BZDs } \\
\text { - CNS depressant: potentiates CNS depressant effects of barbiturates and BZDs } \\
\text { and may increase ECT seizure threshold } \\
\text { - CNS stimulant: may increase anesthetic requirement and decrease ECT seizure } \\
\text { threshold }\end{array}$}} & $\begin{array}{l}\text { - For all herbal medicines: assess } \\
\text { its potential impact on the } \\
\text { procedure, weigh benefits, and } \\
\text { risk } \\
\text { - Similar considerations when } \\
\text { assessing conventional } \\
\text { pharmacotherapy }\end{array}$ \\
\hline Ginseng & & & \\
\hline St Johns Wort & $\begin{array}{l}\text { - GABA agonist: potentiates CNS d } \\
\text { and may increase ECT seizure thre } \\
\text { - Reduces cholinesterase levels: pot } \\
\text { (eg, succinylcholine) } \\
\text { - Inhibits MAO and COMT: hyperte }\end{array}$ & $\begin{array}{l}\text { sant effects of barbiturates and BZDs } \\
\text { tes neuromuscular blockade effect } \\
\text { or cardiovascular collapse }\end{array}$ & \\
\hline
\end{tabular}


Table 2 (Continued)

\begin{tabular}{ll}
\hline Herbals $^{54}$ & Mechanism of action and potential effect on ECT \\
\hline Valerian & - CNS depressant, GABA agonist, inhibits GABA uptake and metabolism: potentiates \\
& CNS effects of barbiturates and BZDs and may increase ECT seizure threshold \\
Kava kava & CNS depressant, GABA agonist: potentiates CNS effects of barbiturates and \\
& BZDs and may increase ECT seizure threshold
\end{tabular}

Abbreviations: BZD, benzodiazepine; CBZ, carbamazepine; ECT, electroconvulsive therapy; FGA, first-generation antipsychotics; LTG, lamotrigine; MAOI, monoamine oxidase inhibitor; SGA, second-generation antipsychotics; SNRIs, serotonin norepinephrine reuptake inhibitors; SSRIs, serotonin reuptake inhibitors; TCA, tricyclic antidepressant; VPA, valporic acid; CNS, Central Nervous System; GERD, Gastroesophageal Reflux Disease; INR, International Normalization Ratio; COMT, Catecholl-OAmine Transferase; GABA, Gamma Amino-Butiric Acid.

\section{Disclosure}

The author reports no conflicts of interest in this work.

\section{References}

1. American Psychiatric Association. The Practice of Electroconvulsive Therapy: Recommendations for Treatment, Training, and Privileging. A Task Force Report of the American Psychiatric Association. 2nd ed. Washington, DC: American Psychiatric Publishing; 2001.

2. Guidelines for Health Authorities in British Columbia. Available from: http://www.health.gov.bc.ca/library/publications/year/2002/ MHA_ect_guidelines.pdf. Accessed January 24, 2016.

3. National Institute of Clinical Excellence (NICE). Guidance on the Use of Electroconvulsive Therapy. NICE; 2003. Available from: https:// www.nice.org.uk/guidance/ta59. Accessed January 24, 2016.

4. Greenberg RM, Kellner CH. Electroconvulsive therapy: a selected review. Am J Geriatr Psychiatry. 2005;13:268-281.

5. Sienaert $P$. What we have learned about electroconvulsive therapy and its relevance for the practising psychiatrist. Can J Psychiatry. 2011; 56(1):5-12.

6. Taylor S. Electroconvulsive therapy: a review of history, patient selection, technique and medication management. South Med J. 2007; 100(5):494-498.

7. Pandya M, Pozuelo L, Malone D. Electroconvulsive therapy: what the internist needs to know. Cleve Clin J Med. 2007;74(9):679-685.

8. Polyakova M, Schroeter ML, Elzinga BM, et al. Brain-derived neurotrophic factor and antidepressive effect of electroconvulsive therapy: systematic review and meta-analyses of the preclinical and clinical literature. PLoS One. 2015;10(11):e0141564.

9. Rose D, Fleischmann P, Wykes T, Leese M, Bindman J. Patients' perspectives on electroconvulsive therapy: systematic review. BMJ.2003; 326:1363.

10. Semkovska M, McLoughlin DM. Objective cognitive performance associated with electroconvulsive therapy for depression: a systematic review and meta-analysis. Biol Psychiatry. 2010;68:568.

11. Read J, Bentall R. The effectiveness of electroconvulsive therapy: a literature review. Epidemiol Psichiatr Soc. 2010;19(4):333-347.

12. Shah AJ, Wadoo O, Latoo J. Electroconvulsive therapy (ECT): important parameters which influence its effectiveness. Br J Med Pract. 2013; 6(4):a634.

13. Ding Z, White PF. Anesthesia for electroconvulsive therapy. Anesth Analg. 2002;94(5):1351-1364.

14. Naguib M, Koorn R. Interactions between psychotropics, anaesthetics and electroconvulsive therapy: implications for drug choice and patient management. CNS Drugs. 2002;16(4):229-247.

15. Galvez V, Hadzi-Pavlovic D, Smith D, Loo CK. Predictors of seizure threshold in right unilateral ultrabrief electroconvulsive therapy: role of concomitant medications and anaesthesia used. Brain Stimul. 2015;8(3):486-492.

16. Rasmussen KG. Propofol for ECT anesthesia a review of the literature. J ECT. 2014;30(3):210-215.

17. Gordon K, Woloschuk DMM, Walus AN. Patients' physical response to thiopental and alternative anesthetic agents in the setting of electroconvulsive therapy. Can J Hosp Pharm. 2014;67(6):447-452.
18. Lihua P, Su M, Ke W, Ziemann-Gimmel P. Different regimens of intravenous sedatives or hypnotics for electroconvulsive therapy (ECT) in adult patients with depression. Cochrane Database Syst Rev. 2014;4: CD009763.

19. Eser D, Nothdurfter C, Schüle C, et al. The influence of anaesthetic medication on safety, tolerability and clinical effectiveness of electroconvulsive therapy. World J Biol Psychiatry. 2010;11(2 pt 2): $447-456$.

20. Janouschek H, Nickl-Jockschat T, Haeck M, Gillmann B, Grözinger M. Comparison of methohexital and etomidate as anesthetic agents for electroconvulsive therapy in affective and psychotic disorders. J Psychiatr Res. 2013;47(5):686-693.

21. Rasmussen KG, Kung S, Lapid MI, et al. A randomized comparison of ketamine versus methohexital anesthesia in electroconvulsive therapy. Psychiatry Res. 2014;215(2):362-365.

22. Akcaboy ZN, Akcaboy EY, Yigitbasł B, et al. Effects of remifentanil and alfentanil on seizure duration, stimulus amplitudes and recovery parameters during ECT. Acta Anaesthesiol Scand. 2005;49:1068-1071.

23. Chen ST. Remifentanil: a review of its use in electroconvulsive therapy. J ECT. 2011;27(4):323-327.

24. Loo C, Simpson B, MacPherson R. Augmentation strategies in electroconvulsive therapy. J ECT. 2010;26(3):202-207.

25. Rabheru K. The use of electroconvulsive therapy in special patient populations. Can J Psychiatry. 2001;46(8):710-719.

26. Mirzakhani H, Welch CA, Eikermann M, Nozari A. Neuromuscular blocking agents for electroconvulsive therapy: a systematic review. Acta Anaesthesiol Scand. 2012;56(1):3-16.

27. Saito S. Anesthesia management for electroconvulsive therapy: hemodynamic and respiratory management. J Anesth. 2005;19(2): 142-149.

28. Aydogan MS, Yücel A, Begec Z, Colak YZ, Durmus M. The hemodynamic effects of dexmedetomidine and esmolol in electroconvulsive therapy: a retrospective comparison. J ECT. 2013;29(4):308-311.

29. Dolenc TJ, Rasmussen KG. The safety of electroconvulsive therapy and lithium in combination: a case series and review of the literature. JECT. 2005;21:165-170.

30. Hategan A, Bourgeois JA. Should lithium and ECT be used concurrently in geriatric patients? Curr Psychiatry. 2014;13(8):e1-e2.

31. Sartorius A, Wolf J, Henn FA. Lithium and ECT-concurrent use still demands attention: three case reports. World J Biol Psychiatry. 2005; 6(2):121-124.

32. Sienaert P, Peuskens J. Anticonvulsants during electroconvulsive therapy: review and recommendations. J ECT. 2007;23:120-123.

33. Hızlı Sayar G, Eryılmaz G, Şemieoğlu S, Özten E, Göğcegöz Gül I. Influence of valproate on the required dose of propofol for anesthesia during electroconvulsive therapy of bipolar affective disorder patients. Neuropsychiatr Dis Treat. 2014;10:433-438.

34. Bundy BD, Hewer W, Andres FJ, Gass P, Sartorius A. Influence of anesthetic drugs and concurrent psychiatric medication on seizure adequacy during electroconvulsive therapy. J Clin Psychiatry. 2010;71(6): 775-777.

35. Sienaert P, Roelens Y, Demunter H, Vansteelandt K, Peuskens J, Van Heeringen C. Concurrent use of lamotrigine and electroconvulsive therapy. J ECT. 2011;27(2):148-152. 
36. Ye L, Karlapati SK, Lippmann S. Topiramate for post-electroconvulsive therapy headaches. J ECT. 2013;29(3):e49.

37. Dolenc TJ, Habl SS, Barnes RD, Rasmussen KG. Electroconvulsive therapy in patients taking monoamine oxidase inhibitors. J ECT. 2004; 20:258-261.

38. Attri JP, Bala N, Chatrath V. Psychiatric patient and anaesthesia. Indian J Anaesth. 2012;56(1):8-13.

39. Peck T, Wong A, Norman E. Anaesthetic implications of psychoactive drugs. Contin Educ Anaesth Crit Care Pain. 2010;10(6):177-181.

40. Dursun SM, Patel JK, Drybala T, Shinkwin R, Drybala G, Reveley MA. Effects of antidepressant treatments on first-ECT seizure duration in depression. Prog Neuropsychopharmacol Biol Psychiatry. 2001;25(2): 437-443.

41. Bernardo M, Navarro V, Salvà J, Arrufat FJ, Baeza I. Seizure activity and safety in combined treatment with venlafaxine and ECT: a pilot study. J ECT. 2000;16(1):38-42.

42. Masdrakis VG, Oulis P, Florakis A, Valamoutopoulos T, Markatou M, Papadimitriou GN. The safety of the electroconvulsive therapyescitalopram combination. J ECT. 2008;24(4):289-291.

43. Dersch R, Zwernemann S, Voderholzer U. Partial status epilepticus after electroconvulsive therapy and medical treatment with bupropion. Pharmacopsychiatry. 2011;44(7):344-346.

44. Okamoto N, Sakamoto K, Yamada N. Transient serotonin syndrome by concurrent use of electroconvulsive therapy and selective serotonin reuptake inhibitor: a case report and review of the literature. Case Rep Psychiatry. 2012;2012:215214.

45. Klysner R, Bendsen BB, Hansen MS. Transient serotonin toxicity evoked by combination of electroconvulsive therapy and fluoxetine. Case Rep Psychiatry. 2014;2014:162502.
46. Nothdurfter C, Eser D, Schüle C, et al. The influence of concomitant neuroleptic medication on safety, tolerability and clinical effectiveness of electroconvulsive therapy. World J Biol Psychiatry. 2006;7(3): 162-170.

47. Boman B. Concurrent use of ECT and cholinesterase inhibitor medications. Aust N Z J Psychiatry. 2002;36(6):816.

48. Rao NP, Palaniyappan P, Chandur J, Venkatasubramanian G, Gangadhar BN. Successful use of donepezil in treatment of cognitive impairment caused by maintenance electroconvulsive therapy: a case report. J ECT. 2009;25(3):216-218.

49. Zahoor MU, Masroor R, Ali MW. Use of lignocaine or nitroglycerine for blunting of hemodynamic stress response during electroconvulsive therapy. Egypt J Anaesth. 2014;30(1):27-30.

50. Wajima Z, Yoshikawa T, Ogura A, Shiga T, Inoue T, Ogawa R. The effects of intravenous lignocaine on haemodynamics and seizure duration during electroconvulsive therapy. Anaesth Intensive Care. 2002;30(6): 742-746.

51. Tess A, Smetana GW. Medical consultation for electroconvulsive therapy. In: Auerbach AD, Park L, editors. UpToDate. Waltham, MA UpToDate; 2015. Accessed December 15, 2015.

52. Mehta V, Mueller P, Gonzlez-Arriaza H, Pankratz S, Rummans T. Safety of Electroconvulsive therapy in patients receiving long-term warfarin therapy. Mayo Clin Proc. 2004;79(11):1396-1401.

53. Bleich S, Degner D, Scheschonka A. Electroconvulsive therapy and anticoagulation. Can J Psychiatry. 2000;45:87.

54. Patra KK, Coffey CE. Implications of herbal alternative medicine for electroconvulsive therapy. J ECT. 2004;20:186-194.
Neuropsychiatric Disease and Treatment

\section{Publish your work in this journal}

Neuropsychiatric Disease and Treatment is an international, peerreviewed journal of clinical therapeutics and pharmacology focusing on concise rapid reporting of clinical or pre-clinical studies on a range of neuropsychiatric and neurological disorders. This journal is indexed on PubMed Central, the 'PsycINFO' database and CAS,

\section{Dovepress}

and is the official journal of The International Neuropsychiatric Association (INA). The manuscript management system is completely online and includes a very quick and fair peer-review system, which is all easy to use. Visit http://www.dovepress.com/testimonials.php to read real quotes from published authors. 